\title{
Similarities in Seed and Aphid Transmission Among Soybean mosaic virus Isolates
}

Leslie L. Domier, Department of Crop Sciences, University of Illinois, United States Department of AgricultureAgricultural Research Service, Urbana, IL 61801; Todd A. Steinlage, Houston A. Hobbs, Yi Wang, and Gabriel Herrera-Rodriguez, Centro Interdisciplinario de Investigación para el Desarrollo Integral Regional, IPN, Unidad Sinaloa, Guasave, Sinaloa, Mexico; and James S. Haudenshield, Nancy K. McCoppin, and Glen L. Hartman, Department of Crop Sciences, University of Illinois, United States Department of Agriculture-Agricultural Research Service, Urbana, IL 61801

\begin{abstract}
Domier, L. L., Steinlage, T. A., Hobbs, H. A., Wang, Y., Herrera-Rodriguez, G., Haudenshield, J. S., McCoppin, N. K., and Hartman, G. L. 2007. Similarities in seed and aphid transmission among Soybean mosaic virus isolates. Plant Dis. 91:546-550.

Soybean mosaic virus (SMV) is an aphid- and seed-transmitted virus that infects soybean (Glycine $\max$ ) plants and causes significant yield losses. Seed-borne infections are the primary sources of inoculum for SMV infections. The strain specificity of SMV transmission through seed and SMV-induced seed-coat mottling were investigated in field experiments. Six soybean plant introductions (PIs) were inoculated with eight SMV strains and isolates. Transmission of SMV through seed ranged from 0 to $43 \%$, and isolate-by-soybean line interactions occurred in both transmission rates and percentages of mottled seeds. For example, SMV 746 was transmitted through $43 \%$ of seed in PI 229324, but was not transmitted through seed of PIs 68522, 68671, or 86449. In contrast, SMV 413 was transmitted through seed from all PIs. SMVs that were transmitted poorly by the Asian soybean aphid, Aphis glycines, also were transmitted poorly through seed. No predicted amino acid sequences within the helper-component protease or coat protein coding regions differentiated the two groups of SMV strains. The loss of aphid and seed transmissibility by repeated mechanical transmission suggests that constant selection pressure is needed to maintain the regions of the SMV genome controlling the two phenotypes from genetic drift and loss of function.
\end{abstract}

Additional keywords: posttranscriptional gene silencing

Soybean mosaic virus (SMV) is an aphid- and seed-transmitted member of the Potyviridae that infects soybean (Glycine $\max \mathrm{L}$.) plants and causes significant losses in the amount and quality of seeds harvested $(18,20)$. Since SMV rarely infects alternative host species, seedborne infections are the primary sources of inoculum for SMV infections (18). Controlling seed-borne SMV infections has become more important with the discovery of Aphis glycines Matsumara in North America, which can efficiently transmit SMV among soybean plants $(10,13,19)$. SMV isolates can be divided into strains ( $\mathrm{G} 1$ through $\mathrm{G} 7$ ) based on the symptoms they produce on a differential set of soybean lines $(9,36)$. In addition to differing in symptom severity, SMV strains G1 through G7 also differ in the efficiency with which they are transmitted

Corresponding author: L. L. Domier

E-mail: ldomier@uiuc.edu

Accepted for publication 15 November 2006.

doi:10.1094/PDIS-91-5-0546

This article is in the public domain and not copyrightable. It may be freely reprinted with customary crediting of the source. The American Phytopathological Society, 2007. through seeds of different soybean lines (7).

As with other members of the Potyviridae, the efficiency with which SMV is transmitted through seed is dependent upon the strain of virus analyzed and the genotype of the host. While differences in seed transmission of Pea seed borne mosaic virus (PSbMV) were associated with the inability of poorly seed-transmitted virus isolates to invade embryos (42), Bowers and Goodman (6) reported that cultivar-specific differences in seed transmission of a severe isolate of SMV were related to differences in the abilities of SMV strains to remain infectious within maturing embryos. Seed-transmissible strains of PSbMV were shown to enter developing embryos through a transient symplastic pathway that connects the base of the suspensor to the developing embryo (37). Isolates of PSbMV not transmitted through seed infected the testa, but were unable to invade and infect developing embryos. In contrast, infectious SMV was found in both the testa and embryo of immature seeds of a soybean cultivar with very low seed transmission, but only in the testa after seeds had desiccated (6).

Johansen et al. (25) showed that regions of the PSbMV genome that encode the helper component/protease (HC-Pro) and coat protein $(\mathrm{CP})$ contained determinants for seed transmission. HC-Pro is a multifunctional protein that, in addition to its role in seed transmission, facilitates aphid transmission (33) and long-distance movement (12), binds RNA (28), and is a potent suppressor of posttranscriptional gene silencing (PTGS) (2). Much like HCPro, the $\gamma \mathrm{b}$ protein of Barley stripe mosaic virus (BSMV) has been shown to be involved in both seed transmission and suppression of PTGS $(14,44)$. Similarly, the $12 \mathrm{~K}$ protein of Pea early browning virus is a determinant of seed transmission (41), and the corresponding protein of Tobacco rattle virus is a suppressor of PTGS (35). These findings suggest that specific movement and/or protection of viral RNA from PTGS-mediated degradation are involved in transmission of viruses through seed.

Bowers and Goodman (7) also reported SMV strain-by-soybean line interactions in seed-coat mottling. In cultivated soybean, the distribution of anthocyanin and proanthocyanidin pigments in seed coats is controlled by four alleles at the $I$ locus (4). Alleles that suppress the accumulation of pigments in seed coats contain inverted repeats of the chalcone synthase (CHS) gene cluster $(11,40)$. The structure of the $I$ locus leads to PTGS of CHS mRNAs that results in yellow-colored soybean seeds. SMV infections, presumably through the action of HC-Pro, induce seed-coat mottling by partially suppressing silencing of the CHS mRNAs (38). The strain-by-line interactions in seed transmission and seedcoat mottling suggest that there are very specific interactions of virus and host components in movement of SMV into soybean embryos and/or survival of SMV in maturing seeds and suppression of silencing.

The genetics of seed transmission also have been examined. With hosts of BSMV, resistance to seed transmission is controlled by a single recessive gene (8). In contrast, seed transmission of PSbMV and Alfalfa mosaic virus is controlled by multiple genes in a quantitative manner $(32,43)$. The genetics of resistance to seed transmission of SMV have not been characterized (22).

In this study, we compared seed transmission of four laboratory strains of SMV 
(G2, G5, G7, and G7F) that had been maintained by mechanical inoculation and four field SMV isolates (413, 746, 1083, and 88799) that had been maintained by aphid or seed transmission, with the goal of establishing a system to investigate viral and host determinants of strain-specific transmission of SMV through seed. Because of the roles of HC-Pro and virus stability in transmission of potyviruses through seed, the predicted amino acid sequences of the HC-Pro and CP coding regions were determined for each virus isolate and compared to their seed and aphid transmission phenotypes.

\section{MATERIALS AND METHODS}

Plant material and virus isolates. Seeds of plant introductions (PIs) PI 68522, PI 68671, PI 84657, PI 86449, PI 88799, and PI 229324 were obtained from the USDA Soybean Germplasm Collection, Urbana, IL. Prior to use in seed transmission studies, each PI was grown in an insect-free greenhouse, and seeds were collected from plants that were negative for SMV infection by double-antibody sandwich enzyme-linked immunosorbent assay (DAS-ELISA) using antibodies from Agdia (Elkhart, IN). SMV strains G2 and G7 were provided by J. Hill (Iowa State University, Ames); SMV G5 was obtained from American Type Culture Collection (Manassas, VA); and G7F was recovered from an original culture of $\mathrm{Cho}$ and Goodman (9). SMV isolates 413, 746, and 1083 were collected from field plots on the Crop Sciences Research and Education Center in Urbana, IL (13). SMV isolate 88799 was obtained from infected seeds of PI 88799. SMV strains G2, G5, G7, and G7F were maintained by mechanical inoculation. SMV isolates 413, 746, and 1083 were maintained through transmission by $A$. glycines on cultivar Williams 82. SMV isolate 88799 was maintained by seed transmission on PI 88799. Virus extracts for mechanical inoculations were prepared from infected soybean plants maintained in the greenhouse by grinding infected leaves with sterilized mortars and pestles in chilled $25 \mathrm{mM}$ potassium phosphate buffer, $\mathrm{pH} 7.1,10 \mathrm{mM} \mathrm{Na} 2 \mathrm{SO}_{3}$. Unifoliate leaves were dusted with Carborundum (320 grit, Fisher, Fairlawn, NJ) and inoculated by rubbing with pestles dipped in inoculum.

Seed and aphid transmission. Field experiments were conducted to compare the rates at which isolates of SMV were transmitted through seed. The six soybean PIs were inoculated separately at the unifoliate growth stage with eight SMV strains and isolates $(\mathrm{G} 2, \mathrm{G} 5, \mathrm{G} 7, \mathrm{G} 7 \mathrm{~F}, 413,746$, 1083, and 88799). All infections were confirmed by DAS-ELISA. Plants were grown to maturity and seeds were harvested and stored at $4{ }^{\circ} \mathrm{C}$. Seed transmission rates were determined by planting up to 200 seeds from infected plants in 96well polystyrene trays containing soilless mix (Sunshine Mix LC1, Sun Gro Horticulture Inc., Bellevue, WA). SMV infections were detected using a tissue blot assay (27). For virus-host combinations that produced less than 200 seeds, all available seeds were analyzed. Samples with ambiguous results from tissue blots were retested by ELISA.

Field experiments were conducted during 2003 and 2004 in field cages $3 \times 3 \mathrm{~m}$ and $1.5 \times 3 \mathrm{~m}$ on the Crop Sciences Research and Education Center in Urbana, IL. Cages were covered with 32-mesh screen to exclude insect vectors. Single row plots, $0.5 \mathrm{~m}$ in length and $0.6 \mathrm{~m}$ between rows, were hand sown to obtain six plants per row (one plant of each PI line). Single row plots were inoculated with an individual virus isolate. Plots were arranged in a randomized incomplete block design with three replications. Analysis of variance of seed transmission and mottling data were performed using SAS (version 9.13; SAS Institute, Cary, NC).

Colonies of A. glycines were maintained in controlled environment chambers on cultivar Williams 82, which was also used for the aphid transmission assays. Alate aphids were collected and starved for at least $30 \mathrm{~min}$ and given 2-min access feeds on leaf tissue infected with SMV 88799. Five aphids were transferred to each of 10 soybean seedlings and allowed to feed for at least $24 \mathrm{~h}$ before being transferred to a second environment chamber for $48 \mathrm{~h}$ in which a Hot Shot No-Pest Strip (Chemsico, St. Louis, MO) had been mounted. Subsequently, inoculated plants were maintained in a greenhouse for 4 weeks and assayed by tissue blot assay. Aphid transmission phenotypes for SMVs G2, G5, G7, G7F, 413, 746, and 1083 were determined previously (13).

Sequence analysis. The HC-Pro and $\mathrm{CP}$ sequences of SMV G2, G5, G7, G7F, 413, 746, and 1083 were determined previously (13). HC-Pro and CP nucleotide sequences of SMV 88799 were determined by direct sequencing of polymerase chain reaction (PCR) products (13). Sequences were aligned using ClustalX (23) and edited with GeneDoc (30).

\section{RESULTS}

Seed transmission and mottling. In both trials, SMV strains were differentially transmitted through seed (Table 1). Transmission of SMV through seed ranged from 0 to $43 \%$ depending on the soybean line and virus strain analyzed (Table 1). In addition, significant $(P<0.001)$ SMV isolate-by-soybean line interactions were seen in germination and seed-coat mottling (Tables 1 and 2). SMV isolates 746 and 88799 showed the largest differences in transmission rates among soybean lines. More than $20 \%$ of the seedlings germi-

Table 1. Percent transmission of Soybean mosaic virus (SMV) isolates through seed and percent germination of seeds

\begin{tabular}{|c|c|c|c|c|c|c|c|c|c|c|c|c|c|}
\hline \multirow{3}{*}{$\begin{array}{l}\text { SMV } \\
\text { strain } \\
\mathrm{G} 2\end{array}$} & \multirow{3}{*}{$\frac{\text { Trial }^{\mathbf{w}}}{1}$} & \multicolumn{12}{|c|}{ Percent germinated seedlings infected with SMV } \\
\hline & & \multicolumn{2}{|c|}{ PI 68522} & \multicolumn{2}{|c|}{ PI 68671} & \multicolumn{2}{|c|}{ PI 84657} & \multicolumn{2}{|c|}{ PI 86449} & \multicolumn{2}{|c|}{ PI 88799} & \multicolumn{2}{|c|}{ PI 229324} \\
\hline & & $0^{\mathrm{x}}$ & $(86)^{\mathrm{y}}$ & 0 & (70) & 1 & (10) & 0 & $(70)$ & 1 & (69) & 0 & (48) \\
\hline & 2 & 0 & (74) & 0 & (48) & 1 & (97) & 0 & (90) & 4 & (74) & 0 & (80) \\
\hline \multirow[t]{2}{*}{ G5 } & 1 & 0 & (92) & 0 & (70) & 4 & (44) & 0 & (92) & 2 & (98) & 19 & (90) \\
\hline & 2 & 0 & $(85)$ & 1 & (88) & 1 & (100) & 0 & (93) & 2 & (96) & 13 & (72) \\
\hline \multirow[t]{2}{*}{ G7 } & 1 & 1 & (54) & 0 & (38) & 0 & (8) & 0 & (58) & 0 & (24) & 8 & (59) \\
\hline & 2 & 0 & $(80)$ & 0 & (33) & 1 & (86) & 1 & (91) & 5 & (98) & 0 & (100) \\
\hline \multirow[t]{2}{*}{ G7F } & 1 & 0 & (44) & 0 & (37) & 0 & (12) & 0 & (48) & 0 & (34) & 0 & (71) \\
\hline & 2 & 0 & (80) & 0 & (39) & 0 & $(85)$ & 0 & (100) & 0 & (67) & 0 & (43) \\
\hline \multirow[t]{2}{*}{413} & 1 & 8 & (71) & 32 & (78) & 19 & (20) & 6 & $(78)$ & 17 & (60) & 31 & (77) \\
\hline & 2 & 13 & (81) & 24 & (75) & 29 & (98) & 5 & (66) & 32 & (84) & 24 & (96) \\
\hline \multirow[t]{2}{*}{746} & 1 & 0 & (79) & 6 & (72) & 0 & (62) & 0 & (100) & 28 & $(80)$ & 43 & (90) \\
\hline & 2 & 0 & (96) & 0 & (92) & 0 & (96) & 0 & $(95)$ & 37 & $(100)$ & 32 & (100) \\
\hline \multirow[t]{2}{*}{1083} & 1 & 10 & (30) & 20 & (66) & 13 & (74) & 0 & (92) & 16 & (71) & 33 & (83) \\
\hline & 2 & 5 & (64) & 0 & (50) & 0 & (73) & 5 & (78) & 12 & (73) & $\mathrm{NS}^{\mathrm{z}}$ & (NS) \\
\hline \multirow[t]{2}{*}{88799} & 1 & 0 & (93) & 0 & (65) & 7 & $(82)$ & 0 & (97) & 29 & (94) & 40 & $(92)$ \\
\hline & 2 & 0 & (89) & 0 & (93) & 0 & (96) & 0 & (68) & 20 & (92) & 22 & (99) \\
\hline
\end{tabular}

\footnotetext{
${ }^{w}$ Trial 1 was conducted during 2003; trial 2 was conducted during 2004. When available, 200 seeds were planted for each line.

${ }^{x}$ Percent germinated seedlings infected with SMV.

y Percent seeds germinated.

z No seeds produced.
} 
Table 2. Percent mottled seeds from Soybean mosaic virus (SMV)-infected field-grown plants

\begin{tabular}{|c|c|c|c|c|c|c|c|}
\hline \multirow{2}{*}{$\begin{array}{l}\text { SMV } \\
\text { strain }\end{array}$} & \multirow[b]{2}{*}{ Trial $^{x}$} & \multicolumn{6}{|c|}{ Percent seeds showing seed-coat mottling } \\
\hline & & PI 68522 & PI 68671 & PI 84657 & PI 86449 & PI 88799 & PI 229324 \\
\hline \multirow[t]{2}{*}{$\mathrm{G} 2$} & 1 & $32^{y}$ & 69 & 93 & 38 & 98 & 100 \\
\hline & 2 & 43 & 62 & 61 & 41 & 96 & 100 \\
\hline \multirow[t]{2}{*}{ G5 } & 1 & 4 & 6 & 4 & 0 & 81 & 82 \\
\hline & 2 & 0 & 0 & 0 & 0 & 77 & 74 \\
\hline \multirow[t]{2}{*}{ G7 } & 1 & 29 & 59 & 86 & 19 & 100 & 87 \\
\hline & 2 & 9 & 30 & 84 & 14 & 95 & 100 \\
\hline \multirow[t]{2}{*}{ G7F } & 1 & 24 & 62 & 94 & 31 & 98 & 100 \\
\hline & 2 & 7 & 71 & 96 & 11 & 100 & 100 \\
\hline \multirow[t]{2}{*}{413} & 1 & 75 & 70 & 62 & 60 & 98 & 100 \\
\hline & 2 & 63 & 39 & 94 & 77 & 96 & 100 \\
\hline \multirow[t]{2}{*}{746} & 1 & 0 & 0 & 0 & 0 & 78 & 79 \\
\hline & 2 & 0 & 0 & 0 & 0 & 85 & 80 \\
\hline \multirow[t]{2}{*}{1083} & 1 & 62 & 60 & 67 & 32 & 100 & 93 \\
\hline & 2 & 84 & 61 & 93 & 81 & 100 & $\mathrm{NS}^{\mathrm{z}}$ \\
\hline \multirow[t]{2}{*}{88799} & 1 & 0 & 0 & 0 & 2 & 86 & 76 \\
\hline & 2 & 0 & 0 & 0 & 0 & 89 & 77 \\
\hline
\end{tabular}

x Trial 1 was conducted during 2003; trial 2 was conducted during 2004.

y Percent mottled seeds from samples of 200 seeds, when available.

z No seeds produced.

nated from field-grown plants of PIs 88799 and 229324 infected with SMVs 746 and 88799 were infected with SMV. But none of the seedlings from similarly field-grown and infected plants of PIs 68522 and 68671 were infected with SMV 746 or 88799. In contrast, SMV 413 was transmitted through seed from all PIs at rates ranging from 5 to $32 \%$. No seed transmission was detected of SMV G7F from either year in the field trials. Data from the 2 years did not differ significantly $(P>0.1)$. The rates of seed transmission (correlation coefficient $=0.85$ ) were highly correlated between years of the field trials, as were percentages of mottled seeds (correlation coefficient $=0.93$ ).

As with seed transmission, significant $(P<0.001)$ SMV isolate-by-soybean line interactions were seen in percentage of seed-coat mottling (Table 2). Soybean lines were separated into four groups based on their mottling responses to different SMV strains (Table 3). At least $74 \%$ of the seeds of PI 88799 and PI 229324 were mottled from plants infected with any one of the eight SMV isolates. In contrast, when the results from the 2 years were averaged, $3 \%$ or less of the seeds of PIs 68522, 68671, 84657, and 86449 were mottled when plants were infected with SMV G5, 746, and 88799. When the same PIs were infected with SMV strains G2, G7, G7F, 413, and 1083, the average percentage of mottled seeds over the 2 years ranged from 15 to $95 \%$. Soybean lines were ranked similarly based on their percentages of seed transmission and seed-coat mottling. PIs 68522 and 86449 had among the lowest mean percentages of seed transmission and seed-coat mottling. PIs 88799 and 229324 had the highest mean percentages of seed transmission and seed-coat mottling (Table 3).

Similar patterns were seen in aphid and seed transmission (Table 4). As a group,
SMV isolates that had been maintained by mechanical inoculation were transmitted by aphids and through seed at significantly lower rates $(0 \%$ aphid transmission and $1 \%$ seed transmission) than SMV isolates that had been maintained by A. glycines or seed transmission (50\% aphid transmission and $13 \%$ seed transmission).

Sequence analysis. The HC-Pro coding regions of all of the highly seed transmissible SMV strains, except SMV 88799, shared two amino acids that the poorly transmitted strains lacked, an $\mathrm{N}$ at position 65 and a $\mathrm{K}$ at position 100 compared with $\mathrm{H}$ or $\mathrm{Q}$ and $\mathrm{R}$, respectively, in the poorly transmitted strains (Table 4). The predicted $\mathrm{CP}$ amino acid sequences of all highly seed transmissible strains $(413,746,1083$, and 88799) had the DAG amino acid triplet near their amino termini, while the $\mathrm{CP}$ sequences of G5, G7, and G7F contained $\mathrm{DAD}, \mathrm{GAD}$, and GAD triplets, respectively. Even though SMVs G2 and 88799 differed in their transmission through seed in field experiments, their HC-Pro and CP predicted amino acid sequences were identical except for an $\mathrm{N}$ to $\mathrm{S}$ substitution at position 449 in HC-Pro.

\section{DISCUSSION}

In this study, we compared the abilities of eight SMV strains to induce seed-coat mottling and to be transmitted through seed and by aphids. As described by Pacumbaba (31), seed coat mottling was not a good indication of seed transmissibility of SMV isolates. Even so, when soybean lines were inoculated with seedtransmissible SMV isolates, seed coat mottling and transmissibility were correlated. Differential transmission of SMV through seed by soybean lines and strainby-line variation in seed transmission and seed coat mottling have been reported previously $(5-7,17)$. Much of the previous analyses were conducted using the Illinois severe isolate of SMV (SMV-Il-S), which
Table 3. Transmission of Soybean mosaic virus (SMV) through seed and seed-coat mottling of six soybean plant introductions

\begin{tabular}{lcc}
\hline & $\begin{array}{c}\text { Seed } \\
\text { transmission }\end{array}$ & $\begin{array}{c}\text { Seed } \\
\text { mottling }\end{array}$ \\
\hline PI 68522 & $2.3 \mathrm{ab}^{\mathrm{y}}$ & $27.0 \mathrm{a}^{\mathrm{z}}$ \\
PI 68671 & $5.1 \mathrm{~b}$ & $36.8 \mathrm{~b}$ \\
PI 84657 & $4.7 \mathrm{~b}$ & $52.1 \mathrm{c}$ \\
PI 86449 & $1.2 \mathrm{a}$ & $25.4 \mathrm{a}$ \\
PI 88799 & $12.8 \mathrm{c}$ & $92.3 \mathrm{~d}$ \\
PI 229324 & $17.6 \mathrm{~d}$ & $89.9 \mathrm{~d}$ \\
\hline
\end{tabular}

y Values within a column with the same letters are not significantly different $(P<0.05)$. Least significant difference $(\mathrm{LSD})=3.2$.

${ }^{\mathrm{z}} \mathrm{LSD}=7.2$.

was later reclassified as SMV G2 (9). In experiments conducted by Bowers and Goodman (7), SMVs G1 through G7 all were transmitted efficiently through seed for a set of soybean lines. In the present study, however, SMVs G2, G5, G7, and G7F were transmitted poorly through seed of all soybean lines analyzed. For example, SMV-Il-S was transmitted through 29 and $34 \%$ of seed of PIs 84657 and 229324, respectively (5); but in this study, SMV G2 was transmitted through seed at rates of 1 and $0 \%$ in the same PIs. These differences in seed transmissibility probably result from the repeated mechanical transmission of the laboratory strains that has occurred in the nearly 30 years since the original experiments were conducted.

Repeated serial transmission of potyviruses has been shown to lead to loss of aphid transmissibility $(15,39)$, which has been associated with amino acid sequence changes in the HC-Pro and CP coding regions (29). Mutations in three amino acids, DAG, near the amino terminus of the CP have been shown to result in loss of transmission by aphids for multiple potyviruses $(3,21)$. In this study, most poorly seed- and aphid-transmitted SMV isolates had mutations in the DAG motif. However, some potyviruses, e.g., isolates of PSbMV, do not have DAG triplets and are still transmitted efficiently by aphids and through seed (26). While HC-Pro and CP have been implicated in both aphid and seed transmission (26), different regions of the proteins may be involved in the two modes of transmission. It is also possible that mechanical transmission of SMV exerted a selection for virus structures that were less compatible with aphid and seed transmission.

The association of seed and aphid transmissibility suggested that sequences required for aphid and seed transmission need constant selection to avoid genetic drift and loss of function. Recently, Ali et al. (1) showed that aphid transmission of Cucumber mosaic virus represented a bottleneck that reduced the number of mutations in transmitted viruses. Similarly, transmission of SMV through seed resulted in the selection of viruses that often 
Table 4. Predicted helper component/protease (HC-Pro) and coat protein (CP) amino acid sequences, percent seed-coat mottling and seed and aphid transmission phenotypes of Soybean mosaic virus (SMV) strains

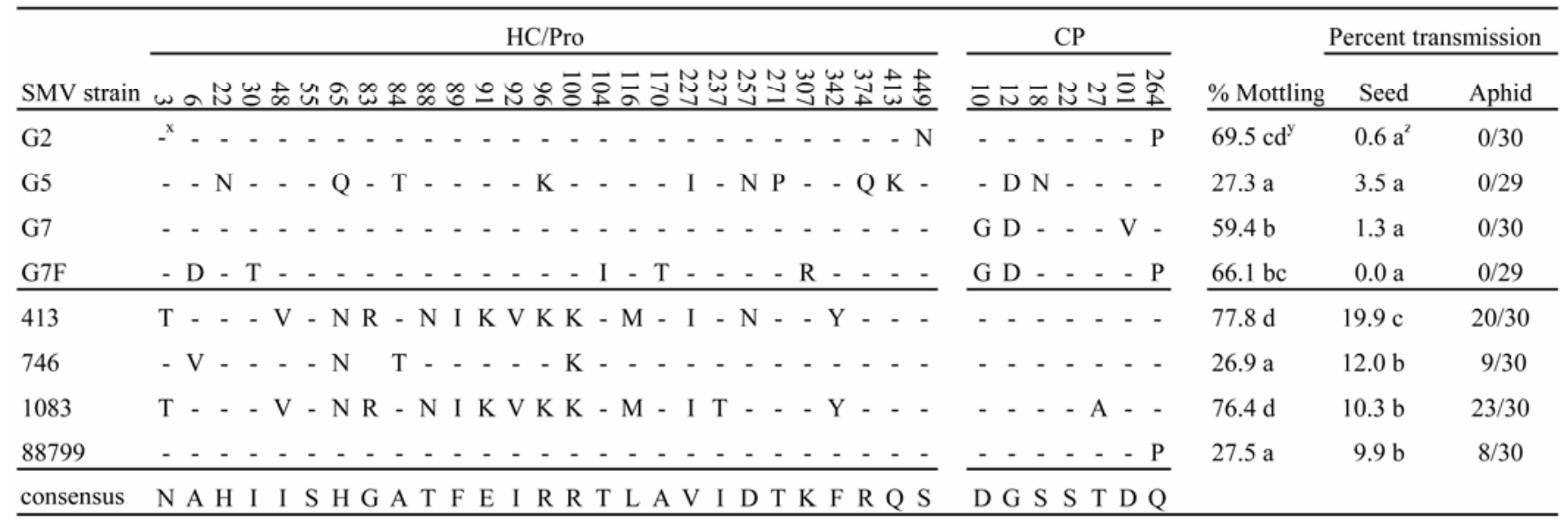

${ }^{x}$ Amino acids are same as consensus.

y Values within a column with the same letters are not significantly different $(P<0.05)$. Least significant difference $($ LSD $)=8.4$.

${ }^{\mathrm{z}} \mathrm{LSD}=3.7$

had different virulence phenotypes than the virus used for inoculation (16).

The findings of Johansen et al. (25) that $\mathrm{CP}$ and HC-Pro coding regions of the PSbMV genome were required for efficient transmission through seed of Pisum sativum are consistent with the association between aphid and seed transmissibility observed here. For a virus to be transmitted through seed, it must infect embryos and survive seed desiccation (24). Brown and Goodman $(6,34)$ showed that both seed-transmissible and nontransmissible strains of SMV invaded soybean embryos, but only SMVs that remained infectious were transmitted through seed. The involvement of CP may be related to differential stabilities of virions of different isolates. Variation in HC-Pro amino acid sequence may alter the protein's ability to bind virions, aphid stylets, or RNA, or its ability to suppress PTGS. Since seed transmission is an important source of SMV infections (18), viruses that are efficiently transmitted both vertically and horizontally would, undoubtedly, be more readily dispersed within and among soybean fields than viruses lacking one of these modes of transmission. Additional studies will be required to identify the SMV and soybean genes involved in seed transmission.

\section{ACKNOWLEDGMENTS}

This work was supported by the United States Department of Agriculture Cooperative State Research, Education, and Extension and Agricultural Research Services, the Illinois Soybean Association, and the North Central Soybean Research Program. Mention of a trademark, proprietary product, or vendor does not constitute a guarantee or warranty of the product by the USDA or the University of Illinois and does not imply its approval to the exclusion of other products or vendors that may also be suitable.

\section{LITERATURE CITED}

1. Ali, A., Li, H., Schneider, W. L., Sherman, D. J., Gray, S., Smith, D., and Roossinck, M. J. 2006. Analysis of genetic bottlenecks during horizontal transmission of Cucumber mosaic virus. J. Virol. 80:8345-8350.

2. Anandalakshmi, R., Pruss, G. J., Ge, X., Marathe, R., Mallory, A. C., Smith, T. H., and Vance, V. B. 1998. A viral suppressor of gene silencing in plants. Proc. Natl. Acad. Sci. USA 95:13079-13084.

3. Atreya, C. D., Raccah, B., and Pirone, T. P. 1990. A point mutation in the coat protein abolishes aphid transmissibility of a potyvirus. Virology 178:161-165.

4. Bernard, R. L., and Weiss, M. G. 1973. Qualitative genetics. Pages 117-149 in: Soybeans: Improvement, Production, and Uses. B. E. Caldwell, ed. American Society of Agronomy, Madison, WI.

5. Bowers, G. R., Jr. 1977. Seed transmission of soybean mosaic virus. University of Illinois, Urbana.

6. Bowers, G. R., Jr., and Goodman, R. M. 1979. Soybean mosaic virus: Infection of soybean seed parts and seed transmission. Phytopathology 69:569-572.

7. Bowers, G. R., and Goodman, R. M. 1991. Strain specificity of soybean mosaic virus seed transmission in soybean. Crop Sci. 31:11711174

8. Carroll, T. W., Gossel, P. L., and Hockett, E. A. 1979. Inheritance of resistance to seed transmission of barley stripe mosaic virus in barley. Phytopathology 69:431-433.

9. Cho, E. K., and Goodman, R. M. 1979. Strains of soybean mosaic virus: Classification based on virulence in resistant soybean cultivars. Phytopathology 69:467-470.

10. Clark, A. J., and Perry, K. L. 2002. Transmissibility of field isolates of soybean viruses by Aphis glycines. Plant Dis. 86:1219-1222.

11. Clough, S. J., Tuteja, J. H., Li, M., Marek, L. F., Shoemaker, R. C., and Vodkin, L. O. 2004. Features of a $103-\mathrm{kb}$ gene-rich region in soybean include an inverted perfect repeat cluster of $\mathrm{CHS}$ genes comprising the $I$ locus. Genome 47:819-831.

12. Cronin, S., Verchot, J., Haldeman-Cahill, R., Schaad, M. C., and Carrington, J. C. 1995. Long-distance movement factor: A transport function of the potyvirus helper component proteinase. Plant Cell 7:549-559.

13. Domier, L. L., Latorre, I. J., Steinlage, T. A., McCoppin, N., and Hartman, G. L. 2003. Variability and transmission by Aphis glycines of North American and Asian Soybean mosaic virus isolates. Arch. Virol. 148:1925-1941.

14. Edwards, M. C. 1995. Mapping of the seed transmission determinants of barley stripe mo- saic virus. Mol. Plant-Microbe Interact. 8:906915.

15. Evans, I. R., and Zettler, F. W. 1970. Aphid and mechanical transmission properties of bean yellow mosaic virus isolates. Phytopathology 60:1170-1174.

16. Fletcher, J., and Goodman, R. M. 1984. Instability of virulence characters of soybean mosaic virus strains after seed transmission. Soybean Genet. Newsl. 11:83-85.

17. Goodman, R. M., Bowers, G. R., Jr., and Paschal, E. H., II. 1979. Identification of soybean germplasm lines and cultivars with low incidence of soybean mosaic virus transmission through seed. Crop Sci. 19:264-267.

18. Hill, J. H. 1999. Soybean Mosaic Virus. Pages 70-71 in: Compendium of Soybean Diseases. G. L. Hartman, J. B. Sinclair, and J. C. Rupe, eds. American Phytopathological Society, St. Paul, MN.

19. Hill, J. H., Alleman, R., Hogg, D. B., and Grau, C. R. 2001. First report of transmission of Soybean mosaic virus and Alfalfa mosaic virus by Aphis glycines in the new world. Plant Dis. 85:561.

20. Hobbs, H. A., Hartman, G. L., Wang, Y., Hill, C. B., Bernard, R. L., Pedersen, W. L., and Domier, L. L. 2003. Occurrence of seed coat mottling in soybean plants inoculated with Bean pod mottle virus and Soybean mosaic virus. Plant Dis. 87:1333-1336.

21. Husted, K. 1995. Reason for non-aphid transmissibility in a strain of Kalanchoe mosaic potyvirus. Virus Genes 11:59-61.

22. Irwin, M. E., and Goodman, R. M. 1981 Ecology and control of soybean mosaic virus. Pages 181-229 in: Plant Diseases and Vectors: Ecology and Epldemiology. K. Maramorosch and K. F. Harris, eds. Academic Press, New York.

23. Jeanmougin, F., Thompson, J. D., Gouy, M., Higgins, D. G., and Gibson, T. J. 1998. Multiple sequence alignment with Clustal X. Trends Biochem. Sci. 23:403-405.

24. Johansen, E., Edwards, M. C., and Hampton, R. O. 1994. Seed transmission of viruses Current perspectives. Annu. Rev. Phytopathol. 32:363-386.

25. Johansen, I. E., Dougherty, W. G., Keller, K. E., Wang, D., and Hampton, R. O. 1996. Multiple viral determinants affect seed transmission of pea seedborne mosaic virus in Pisum sativum. J. Gen. Virol. 77:3149-3154.

26. Johansen, I. E., Keller, K. E., Dougherty, W. G., and Hampton, R. O. 1996. Biological and molecular properties of a pathotype $\mathrm{P}-1$ and a 
pathotype P-4 isolate of pea seed-borne mosaic virus. J. Gen. Virol. 77:1329-1333.

27. Lin, N. S., Hsu, Y. H., and Hsu, H. T. 1990. Immunological detection of plant viruses and a mycoplasmalike organism by direct tissue blotting on nitrocellulose membranes. Phytopathology 80:824-828.

28. Maia, I. G., and Bernardi, F. 1996. Nucleic acid-binding properties of a bacterially expressed potato virus $\mathrm{Y}$ helper componentproteinase. J. Gen. Virol. 77:869-877.

29. Ng, J. C., and Falk, B. W. 2006. Virus-vector interactions mediating nonpersistent and semipersistent transmission of plant viruses. Annu. Rev. Phytopathol. 44:183-212.

30. Nicholas, K. B., Nicholas, H. B. J., and Deerfield, D. W. I. 1997. GeneDoc: Analysis and visualization of genetic variation. EMBNEW.NEWS 4:14.

31. Pacumbaba, R. P. 1995. Seed transmission of soybean mosaic virus in mottled and nonmottled soybean seeds. Plant Dis. 79:193-195.

32. Pathipanawat, W., Jones, R. A. C., and Sivasithamparam, K. 1997. Factors influencing transmission of alfalfa mosaic virus through seed of annual medics (Medicago spp.) and the genetic control of seed transmission rate. Aust. J. Agric. Res. 48:989-997.

33. Pirone, T. P., and Perry, K. L. 2002. Aphids:
Non-persistent transmission. Pages 1-19 in: Advances in Botanical Research: Plant Virus Vector Interactions. R. T. Plumb and J. A. Callow, eds. Academic Press, London.

34. Porto, M. D. M., and Hagedorn, D. J. 1975. Seed transmission of a Brazilian isolate of soybean mosaic virus. Phytopathology 65:713716.

35. Reavy, B., Dawson, S., Canto, T., and MacFarlane, S. A. 2004. Heterologous expression of plant virus genes that suppress posttranscriptional gene silencing results in suppression of RNA interference in Drosophila cells. BMC Biotechnol. 4:18.

36. Roane, C. W., Tolin, S. A., and Buss, G. R. 1986. Application of the gene-for-gene hypothesis to soybean-soybean mosaic virus interactions. Soybean Genet. Newsl. 13:136139.

37. Roberts, I. M., Wang, D., Thomas, C. L., and Maule, A. J. 2003. Pea seed-borne mosaic virus seed transmission exploits novel symplastic pathways to infect the pea embryo and is, in part, dependent upon chance. Protoplasma 222:31-43.

38. Senda, M., Masuta, C., Ohnishi, S., Goto, K., Kasai, A., Sano, T., Hong, J. S., and MacFarlane, S. 2004. Patterning of virusinfected Glycine max seed coat is associated with suppression of endogenous silencing of chalcone synthase genes. Plant Cell 16:807818.

39. Simons, J. N. 1976. Aphid transmission of a non-aphid transmissible strain of tobacco etch virus. Phytopathology 66:652-654.

40. Todd, J. J., and Vodkin, L. O. 1996. Duplications that suppress and deletions that restore expression from a chalcone synthase multigene family. Plant Cell 8:687-699.

41. Wang, D., MacFarlane, S. A., and Maule, A. J. 1997. Viral determinants of pea early browning virus seed transmission in pea. Virology 234:112-117.

42. Wang, D. W., and Maule, A. J. 1994. A model for seed transmission of a plant virus - Genetic and structural analyses of pea embryo invasion by pea seed-borne mosaic virus. Plant Cell 6:777-787.

43. Wang, D. W., and Maule, A. J. 1997. Contrasting patterns in the spread of two seed-borne viruses in pea embryos. Plant J. 11:1333-1340.

44. Yelina, N. E., Savenkov, E. I., Solovyev, A. G. Morozov, S. Y., and Valkonen, J. P. 2002. Long-distance movement, virulence, and RNA silencing suppression controlled by a single protein in hordei- and potyviruses: Complementary functions between virus families. J. Virol. 76:12981-12991. 